Morris: Internationalizing the University

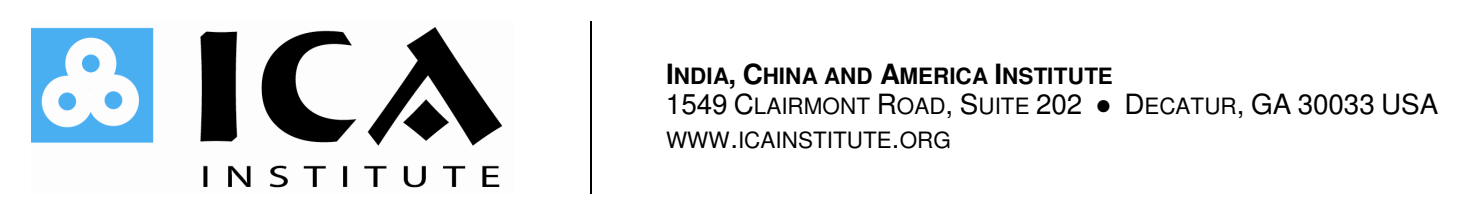

Internationalizing the university: Theory, Practice, Organization and Execution

Barry J. Morris

Journal of Emerging Knowledge on Emerging Markets
Volume 1 Issue 1
November 2009 


\section{Internationalizing the University: Theory, Practice, Organization and Execution}

Barry J. Morris, Ph.D. Executive Director of the Institute for Global Initiatives Director of Cabinet Strategic Projects Kennesaw State University

Journal of Emerging Knowledge on Emerging Markets Volume 1 Issue 1 November 2009

L eading universities around the globe have begun to internationalize their campuses. This effort is being driven by historic political and economic changes, changes in the academic and nonacademic environment, and by the strategic imperative for universities to remain at the forefront of its teaching, research and service missions. ${ }^{1}$ Universities are being asked to help meet major international challenges, to educate students in their disciplines with a sense of global competence and engagement, and to contribute to local and national economic competiveness. Faculty members must not only remain current in their disciplines globally but must also be aware of developments in key related disciplines since the nature of knowledge and the problems facing humanity are cross-disciplinary and global. How can leaders understand and manage these demands?

Within a framework of theory, practice, organization and execution, this paper will address:

1. Fundamental causes of university internationalization

2. Key measures of success in internationalization

3. Fundamental actions necessary for effective internationalization

${ }^{1}$ The author would like to thank the Turkmenistan Ministry of Education, Academy of Sciences, and the Chamber of Industry and Trade who sponsored the conference "Science and Education of the New Revival Epoch in the Global Science and Education Science" in September 2009 where many of the ideas included in this paper were first presented. A Russian version of this paper, translated by the author, is available here: http://www.icainstitute.org/documents/morris russian.pdf. 
4. Strategic planning and internationalization

5. Foundational international knowledge, skills, and attitudes for all students and faculty

6. The intersection of internationalization and multiculturalism

7. Models for internationalizing the curriculum

8. Models of institutional organization

9. Challenges and opportunities surrounding study abroad programs

10. Principles of local, national and international collaboration, partnership and expansion

11. An overview of national U.S. organizations, associations and government entities addressing and facilitating internationalization

As an introduction, I should note that I am using Jane Knight's definition (Knight 2003) of university internationalization: "the process of integrating an international, intercultural, or global dimension into the purpose, functions, or delivery of post-secondary education." I should also note that because of space constraints, my presentation is an overview covering the subject in an abbreviated form. This presentation is not a comprehensive treatment of the subject. Finally, I should also note that I am talking about comprehensive internationalization as an ideal goal and not piecemeal or partial internationalization.

I. There are a number of fundamental causes of university internationalizationinternationalization that includes global learning, teaching, research, curriculum, student life, and community service, outreach \& engagement. I would note four:

1. The first is global integration in the areas of trade, investment, politics, the environment, culture, research, health, etc.-facilitated by advances in information, communication and transportation technologies.

2. The second is the desire of universities to remain current, relevant and innovative in their research, teaching and service missions.

3. The third is the need of universities to train students to find employment and compete in a global marketplace and create research that enhances the reputation of the university and the social and economic development of its local community.

4. The fourth is the desire of universities to achieve a variety of goals including: academic, economic and entrepreneurial, social, national security and foreign policy.

II. There are numerous measures of success in internationalization. Here are a baker's dozen: 
1. A vision and mission statement exists that identifies internationalization as a core value, principle and goal of the university.

2. Number and percentage of students and faculty studying and teaching abroad.

3. Number and percentage of faculty who actively support the goal of comprehensive internationalization.

4. Number and percentage of faculty taking advantage of development opportunities related to global research, teaching and service.

5. Number and percentage of courses and course components that can be characterized as global.

6. Number and percentage of faculty members that have participated in a particular international partnership.

7. Number of co-curricular activities (e.g., student internships, clubs, service learning, etc.).

8. The administrative structure reflects the internationalization goal.

9. Top leadership and dispersed leadership support the goal of internationalization.

10. Funding supports the internationalization goal.

11. There is regular and consistent faculty dialogue on the subject of internationalization leading to a shared understanding of the internationalization goals of a given institution.

12. How does your university compare with comparable institutions?

13. Is a strategic plan in place to execute the internationalization goal?

III. Here is a sample of the fundamental actions necessary for effective internationalization:

1. Define your terms and purpose: e.g., internationalization, globalization, global, intercultural, multicultural, diversity, international education... What do these terms mean to the various constituencies in your institution? How do they relate to the purpose of the strategic plan for internationalization?

2. Construct an internationalization strategic plan with commitment and participation of faculty, administration, and key external partners.

3. Link the internationalization strategic plan to the institution's strategic plan.

4. Hold deans, department chairs, and other administrators accountable for outlining and achieving their internationalization objectives. 
5. Create and maintain administrative entities, devices or structures that insure and promote regular, consistent, and strategically relevant communication.

6. Establish reliable, substantial and predictable funding sources that support key internationalization activities such as student education abroad, faculty development, and global course development.

7. Identify and create champions of internationalization.

8. Articulate expected learning outcomes and determine how these outcomes will be assessed.

9. Recognize and celebrate success.

IV. Here are four key elements for successful strategic planning for internationalization:

1. Inclusion and transparency are critical principles in establishing the plan's legitimacy. All of the major actors that will be affected by the plan, that must support the plan for it to be successful, and that don't support it, should be included in the planning process.

2. Address the key planning categories: Vision \& Mission; Goals; Tasks; Principles; Strengths, Weaknesses, Opportunities \& Threats (SWOT Analysis); Inventory, Audit \& Review of Assets; Measurement \& Assessment...

3. The plan should address the proper balance between centralization and decentralization.

4. The plan should allow for adjustments along the way.

V. I have selected a sample of foundational international knowledge, skills, and attitudes for students and faculty (Olson, et. al., 2005). These will of course be adjusted according to a student's and faculty member's major or area of expertise.

1. Basic Knowledge Outcomes: (a) Understands his or her culture within a global and comparative context (that is, the student recognizes that his or culture is one of many diverse cultures and that alternate perceptions and behaviors may be based in cultural differences); (b) Demonstrates knowledge of global issues, processes, trends, and systems (that is, economic and political interdependency among nations, environmentalcultural interaction, global governance bodies, and nongovernmental organizations); (c) Demonstrates knowledge of other cultures (including beliefs, values, perspectives, practices, and products).

2. Basic Skills: (a) Uses knowledge, diverse cultural frames of reference, and alternate perspectives to think critically and solve problems; (b) Communicates and connects with people in other language communities in 
a range of settings for a variety of purposes, developing skills in each of the four modalities: speaking (productive), listening (receptive), reading (receptive), and writing (productive); (c) Uses foreign language skills and/or knowledge of other cultures to extend his or her access to information, experiences, and understanding.

3. Basic Attitudes: (a) Appreciates the language, art, religion, philosophy, and material culture of different cultures; (b) Accepts cultural differences and tolerates cultural ambiguity; (c) Demonstrates an ongoing willingness to seek out international or intercultural opportunities.

More specialized and general knowledge, skills and attitudes

4. Training in the theory and practice of intercultural communication skills.

5. Basic knowledge of world history, politics, culture, philosophy and literature.

6. Basic knowledge of the historical and global sources of the sciences; and the global impact of the sciences.

7. Basic knowledge of the academic disciplines and their practice across time, space, and cultures.

VI. The intersection of internationalization and multiculturalism represents an important opportunity to mutually reinforce work in each area (Olson et. al. 2007). I would make one point here:

1. Group differences may be global and local. Take advantage of programs that advance teaching, research, and service in one area to do the same in the other area. Innovative joint planning can lead to a powerful synergistic effect that advances the university more than their separate agendas would have alone.

VII. Models and ideas for internationalizing the curriculum

1. Provide course development grants to individual faculty members from the central administration.

2. Insure that a departmental curriculum committee leads a review of global learning integration.

3. Insure that academic deans request and guide curriculum review for global learning.

4. Consider general education courses, cross-disciplinary courses, and course component development as potential solutions to the problem of "lack of room in the major" preventing the addition of a complete new global learning course. 
VIII. Models and ideas for institutional organization. I would note three basic models for institutional structure:

1. Decentralized (Silo)

\section{Centralized}

3. Hybrid

"Whatever the primary model, a key objective is to balance the substance and politics of centralization and decentralization. As institutions intensify their international activities and as the external environment changes, the need for coordination of internationalization initiatives across the institution becomes increasingly evident. Unfettered decentralization leads to reinvention of the wheel; inconsistency in policies, procedures, and the attendant risks; and less efficient use of resources. However, centralization has its drawbacks and resistors. Schools and colleges treasure their autonomy and resist any efforts that fetter their entrepreneurial spirit or their creativity (p. 18, Hill and Green, 2008)." It is essential that faculty members perceive benefits from centralization and that they perceive any central administrative action as coordinating, and not controlling, their activities.

IX. Even if one could effectively summarize the many books and manuscripts on the subject of Study Abroad, substantial gaps would likely remain. So allow me to make just a few recommendations and observations that may help to meet the challenges and opportunities created by the growth and change in study abroad (NAFSA, 2008):

1. An ideal goal is to integrate education abroad programs with academic major, minor and general education requirements.

2. Faculty and administrators should think broadly about education abroad opportunities in a way that goes beyond coursework and that includes internships, field work, research, service learning...

3. "Democratic practice becomes a central part of global learning when students are engaged with real, unscripted, and complex questionsquestions that cut across national borders and require action from all citizens (p. 5, Hovland 2006)."

4. "Liberal learning and global learning converge when students have multiple opportunities to apply new knowledge to their own developing sense of place in the world (p. 10, Hovland 2006)."

5. We should ask students and ourselves: "What does it mean to be a citizen in the evolving global context?" and "How should one act in the face of large unsolved global problems?" (p. 19, Hovland 2006)

X. Principles of local, national and international collaboration, partnership and expansion. Here are a set of key questions to ask: 
1. Does the university have an overall strategy for international partnerships?

2. Does the university regularly evaluate its partnerships? If so, what criteria are used?

3. Does the university have criteria for deciding whether to pursue potential partnerships?

4. To what extent do faculty members engage in collaborative research and development cooperation with faculty at institutions in other countries?

5. What effect do partnerships have on student international learning?

6. How sustainable are the existing partnerships?

7. Are you moving partnerships from a simple tactic to a guiding principle of internationalization, i.e., from a transactional relationship to a transformational relationship?

8. Are you making promises that you cannot keep and keeping all promises that you make?

XI. Here is a sample of organizations, associations and government entities addressing and facilitating internationalization

1. National Association of International Educators (NAFSA) www.nafsa.org

2. Association of American Colleges and Universities www.aascu.org

3. American Council on Education (ACE) http://www.acenet.edu/Content/NavigationMenu/ProgramsServices/cii/inde x.htm

4. Association of Public and Land-Grant Universities (APLU) http://www.aplu.org/NetCommunity/Page.aspx?pid=570

5. Association of International Education Administrators https://aieaworld.american-data.net/index.php

6. Forum on Education Abroad http://www.forumea.org/

7. U.S. Department of Education, International Affairs Office http://www.ed.gov/about/inits/ed/internationaled/index.html

8. UNESCO's International Association of Universities http://www.unesco.org/iau/

I would like to close with seven questions that may help you think about your institutions internationalization efforts:

\section{Key questions}


1. What are the strengths and weaknesses of the institution's current efforts to internationalize? What opportunities exist for deepening internationalization? What are the threats to future progress?

2. To what extent does synergy exist among the various international activities and programs on campus? What communication channels exist, and how well are they working?

3. What are the most important targets for future collaboration and connection among international programs \& activities on campus?

4. Are only a self-selected group of faculty and students engaged in internationalization?

5. What strategies are in place to help domestic students learn from international students?

6. Does the university have an overall strategy for international partnerships?

7. What opportunities exist in the local environment to enhance internationalization efforts? To what extent does the university take advantage of these opportunities?

\section{References}

American Council on Education, Center for International Initiatives. Conference Workshop: At Home in the World: Educating for Global Connections and Local Commitments. Washington, D.C. June 28-30, 2009.

Brandenberg, U., \& Federkeil, G. (2007, July). How to measure internationality and internationalization of higher education institutions: Indicators and key figures. Centre for Higher Education Development, working paper no. 92, Berlin.

De Wit, Hans, ed. Measuring success in the internationalization of higher education. Occasional Paper 22. European Association for International Education (EAIE). http://www.che.de/downloads/measuring_internationalisation_EAIE_Occasional_Papers_22v6.pdf

Green, M., Luu, D., \& Burris, B. (2008). Mapping internationalization on U.S. campuses: 2008 edition. Washington, D.C.: American Council on Education.

Green, M. \& Olson, C. (2003) Internationalizing the campus: A user's guide Washington, D.C.: American Council on Education.

Green, M., Shoenberg, R. (2006) Where Faculty Live: Internationalizing the Disciplines. Washington, D.C.: American Council on Education.

Green, M. \& Siaya, L. (2005) Measuring Internationalization at Research Universities. Washington, D.C.: American Council on Education [see others in the series including Community Colleges, Comprehensive Universities, \& Liberal Arts Colleges]. 


\section{Internationalizing the University: Theory, Practice, Organization and ExeCution}

Heyl, J.D. (2007) The senior international officer (SIO) as change agent Durham, NC: Association of International Education Administrators.

Hill, Barbara \& Green, Madeleine (2008) A Guide to Internationalization for Chief Academic Officers. Washington, D.C.: American Council on Education

Hovland, Kevin (2006) Shared Futures: Global Learning and Liberal Education. Washington, D.C.: Association of American Colleges and Universities.

Knight, J., (2003, fall) Updating the definition of internationalization. In International Higher Education.

NAFSA Task Force (2008) Strengthening Study Abroad: Recommendations for Effective Institutional Management for Presidents, Senior Administrators, and Study Abroad Professionals (Washington, D.C.: January 2008).

Olson, C., Green, M., \& Hill, B., (2005) Building a strategic framework for comprehensive internationalization.

Olson, C., Green, M., \& Hill B., (2006) A Handbook for Advancing Comprehensive Internationalization: What Institutions Can Do and What Students Should Learn. Washington, D.C.: American Council on Education.

Olson, C., Evans, R. \& Shoenberg, R.F. (2007) At Home in the World: Bridging the Gap Between Internationalization and Multicultural Education Washington, D.C.: American Council on Education.

Sutton, S. (2009) Partnerships for Transformative Internationalization. Workshop presented at the NAFSA Conference Symposium on Leadership. Los Angeles, CA: May 26, 2009. 